\title{
Research on the Importance of Teaching in the Process of Higher Education
}

\author{
Zhiqiang $\mathrm{Xu}$ \\ Department of Physics and Technology \\ Kunming University \\ Kunming 650214, China
}

\begin{abstract}
University teaching and teaching academics are inseparable and important links. The teaching ability directly affects the development of university teaching and students' learning. Although the connotation about academic teaching in universities is different, it does combine the combination of theory and practice. It not only stresses the research of teaching theory, but also emphasizes the teaching academic ability acquired by teachers in the process of teaching practice. By means of teaching practice and teaching research, the formation of teaching academic ability is promoted effectively. The academic characteristics of teaching are embodied in teaching contents, teaching objects, teaching tasks and teaching management. Therefore, good teaching is based on the research of teachers, which improves teaching and creates wonderful classrooms. The essence of teaching research is the activities in which teachers discover the nature of teaching and research into teaching, which is a process of exploring teaching. The emphas is on teaching academics and developing the related teaching evaluation work are important components of enriching academic careers.
\end{abstract}

Keywords-teaching academic; scientific research; university teaching

\section{INTRODUCTION}

At present, there is not only a huge contrast in interest orientation, but also a loss of value orientation in teaching and scientific research in colleges and universities, especially among famous universities, it is generally believed that only scientific research results can show the academic level of professors and the academic strength of universities while teaching can be entrusted to those teachers who do not perform well in scientific research. If this kind of value orientation cannot be fundamentally reversed, it will be impossible to pay enough attention and respect to teaching in colleges and universities. It will not only do great harm to the quality of teaching in universities, but also bring about an urgent need for immediate benefits and vicious competition in universities, leading to astray. In order to solve the contradiction between university teaching and scientific research fundamentally, it is necessary to adjust the relationship between them and to change the orientation of value in order. In fact, university teaching and scientific research are mutually beneficial. However, the biggest difficulty lies in revealing and demonstrating that university teaching has the same academic nature, value and status as scientific research to keep balance and harmonious development of teaching and research. In addition, a whole set of scientific and objective management system of evaluating the academic level of university teaching should be established. Importantly, the system can also be recognized and accepted by university teachers and administrators. The essence of solving this problem is to seek the inner fusion of teaching, scientific research, social service and other functions in the space of globalization and information, which is the only way for the university to develop healthily and sustainably.

\section{FoCUS ON IMPROVING TeAchers' ACADEMIC ABILITy IN TEACHING}

Along with the progress and development of science and technology, the status of higher education is more and more prominent, and the cultivation of talents is paid more and more attention to. Under the background of the current interdisciplinary integration, the improvement of teachers' teaching level will contribute to the cultivation of talents. Therefore, colleges and universities should recognize the academic nature of teaching and the prominent position of teaching in the whole development of higher education. Meanwhile the promotion of teachers' teaching ability should be considered as an important means to promote the professional development of teachers. The importance of academic teaching and the development of related teaching evaluation is an important part of enriching academic cause. Teaching should be brought into academic category and teachers should be actively guided by teaching evaluation based on teaching academic theories in order to promote teachers' teaching level and teaching research ability. In the aspect of teaching evaluation and teaching, the traditional understanding should be abandoned and the prejudice of teaching should be eliminated to measure teaching according to academic standard. At the same time, the idea of attaching importance to scientific research and light teaching should be changed; the teaching academic concept should also be established. Besides, teaching academic theory should be applied to teaching evaluation, promoting the improvement of teachers' teaching and research ability, and encouraging teachers to carry out teaching research. Teachers should take teaching as their duty, actively promote their teaching ability and improve their teaching level. [1] Under the guidance of the teaching academic evaluation system based on the teaching academic theory, teachers themselves should change their teaching concepts; strengthen their consciousness to carry on the teaching plan, applying to their teaching. It is of great 
importance to strengthen the understanding of the teaching process and to innovate teaching methods so as to promote the specialization of teachers.

\section{Strengthen the Exploratory Teaching Process}

The teaching research is a process in which teachers discover the essence of teaching and study teaching activities. [2]Although the teaching of the basic knowledge of the subject is the basic part of teaching, it is not the only one. Improve teaching and learning is the aim of higher education. College teaching is based on the existing knowledge and experience of the subject to cultivate students' ability to learn new knowledge and explore the unknown. Meanwhile, student' creative and divergent thinking are cultivated, which can make students study effectively. Students have the characteristics of variability and uncertainty, which is the most significant difference between teaching and scientific research. Teachers need to explore the variability of students. As adults, college students have a certain degree of cognition and judgment. Their intelligence and psychological level are relatively mature. Therefore, they have their own opinions and views on subject knowledge and related issues. What's more, their subjective consciousness is strong. In addition, teachers also need to adapt to the uncertainty in the teaching process. Although teaching can also be conducted through the teachers' full preparation before class according to the teaching plan, it is difficult to predict the change of teaching situation in the teaching process. The teaching process cannot be exactly the same while the teaching methods are not fixed, so teachers need to adjust their teaching according to the specific teaching situation at any time. The teaching process is promoted through mutual understanding, run-in, cooperation, and exploration between teachers and students. In fact, it is a dynamic, changing and exploring process. No matter how detailed the teaching plan is prepared by the teacher before class, it is impossible to predict the complex and changeable teaching situation that may be encountered in the teaching process. This requires that teachers have the ability to adapt flexibly to the circumstances of the classroom.[3]

\section{Correct The View of Teaching Academic Thought IN TEAching Evaluation System}

Nowadays, many teachers don't think highly of the evaluation of teaching training and management system. Under the influence of traditional academic ideas, there is a phenomenon of narrowing academic connotation in universities That is, academic is considered as scientific research, so teaching does not belong to academic activities. For a long time, it is generally regarded that teaching is the process in which teachers transmit knowledge. Thus, the academic characteristics of teaching such as reflection, communication and discussion are ignored. In the system of teachers evaluation, the evaluation of teaching is not included in academic evaluation. Teaching evaluation is specially separated to form a system, which leads to the deepening and solidification of the idea that teaching activities are not academic activities but technical activities. It is because the academic nature of teaching is obscured that the teachers' appointment system and teachers' evaluation system have been formed based on the number of papers and the number of topics. The evaluation of teaching has become an evaluation mechanism based on classroom evaluation, which ignores the reflection and research on teaching as well as the evaluation of related achievements in teaching in a certain aspect. Famous American education strategist Ernest Boyer reveals and criticizes a narrow and hierarchical understanding of learning in American universities in the famous report-Academic Reflections-teachers' Priority. Scientific research to find new knowledge is simply called an academic activity, while applied research and cross-sectional research, especially the most important teaching activity in a university, is excluded from academic activity, which is considered to be lack of professionalism, normative and creative [1] Starting from the requirements of the times and the actual working conditions of university teachers, Boyer redefines the concept of academy, and tries to cover the rich and diverse academic life of university teachers. It is suggested that academic research be divided into four types: scholarship of discovery, scholarship of integration, scholarship of application, scholarship of teaching.[2] It means not only finding new knowledge, but also synthesizing knowledge, applying knowledge and imparting knowledge. The four kinds of academic ideas have expanded the academic concepts and the academic missions beyond the traditional academic palace, [3] which has brought the brand-new understanding to the scientific research and teaching. Scientific research not only means discovering new knowledge, publishing papers, but also synthesizing the knowledge of different disciplines to open up new fields, and solving the practical problems of society in the creative application of scientific research achievements. This has opened up a new direction of scientific research, the publication and dissemination of scientific research results. It is the broad sense of teaching, in which research and innovation are needed. Therefore, on the one hand teaching means to impart knowledge and bring up future scholars. On the other hand it means to cultivate future academic talents in the process of dialogue and exchange between scholars and young people. This obviously requires teachers to have higher academic literacy, constantly study and track the academic frontier in this field. So good teaching should be based on teachers' scientific research because it has the same characteristics as all other forms of scientific research, which is professional and creative. Teaching is undoubtedly a challenging lifelong academic topic for teachers. [4] Teaching itself is a complex and fascinating study with endless frontiers. Therefore, scientific research and teaching are internal unity and inseparable. This is a profound interpretation of teaching from a broad academic field of vision. More importantly, a new academic way to resolve the contradiction between university teaching and scientific research is put forward.

\section{CONCLUSION}

Through the systematic thinking on the evolution of teaching academic history, this paper synthesizes the teaching academic thoughts represented by Boyer. On the basis of the interpretation, comparison and reflection of academic and teaching concepts, the deep reform of university teaching in the information age is paid attention to. This paper puts forward the definition of teaching academic concepts. It points out that teaching academic concept embodies a broad sense of 
academic and teaching view, highlighting the position and value of teaching in the construction of harmonious and pluralistic academic ecology in universities. It is emphasized that the teaching in the information age should transcend the individual and close teaching mode as well as personnel training mode. The creativity of the teachers and students should be stimulated in the teaching process in the information age, making university curriculum teaching innovation become the learning mode, work style and lifestyle pursued by teachers and students. The harmonious academic teaching, scientific research, application and social service integration should be constructed on this basis. It is a kind of Academic Community, which includes undergraduate students. Taking it as the goal and value orientation, a healthy and harmonious university cultural ecology can surely be constructed.

\section{REFERENCES}

[1] Junchao Zhang, Honggong Wu Reforming the University Organization System and Improving the Relationship between Teaching and Scientific Research. Journal of China University of Geosciences. Social Sciences Edition [J], 2009 (09): 120

[2] YanNiu Ren Reflections and Reconstruction of Teaching Evaluation System in Shanxi Normal University 2011

[3] Limin Yao On the Teachinf of University Teachers [M] . Hunan University Press, 2008

[4] Boyer, E.L. Scholarship Reconsidered: Priorities of the Professoriate Princeton, N.J.: The Carnegic Foundation for the Advancement of Teaching, 1990:15

[5] Boyer, E.L. Scholarship Reconsidered: Priorities of the Professoriate [M]. Princeton, N.J.: The Carnegic Foundation for the Advancement of Teaching, 1990:16

[6] Ernest Boyer Boyer Lecture Collection 1995 Translated by Yanguo Tu, Tong Fang Beijing: Educational Science Press 2002:12

[7] Boyer E. L. Scholarship Reconsidered: Priorities of the Professoriate [M]. Princeton, N.J.: The Carnegic Foundation for the Advancement of Teaching, 1990:24 